\title{
INTELLECTUAL CAPITAL AND DISCLOSURE PRACTICES OF MISCELLANEOUS INDUSTRIES: EVIDENCE FROM CABLE COMPANIES IN INDONESIA
}

\author{
Partiwi Dwi Astuti* \\ Faculty of Economics and Business, Warmadewa University, Indonesia \\ Anis Chariri \\ Faculty of Economics and Business, Diponegoro University, Indonesia \\ Abdul Rohman \\ Faculty of Economics and Business, Diponegoro University, Indonesia
}

\begin{abstract}
The important role of intellectual capital for value creation has led many companies to disclose their intellectual capital information in annual reports. This study aims to provide, via content analysis, an overview of the disclosure and presentation of intellectual capital information in the annual reports of cable companies listed on the Indonesia Stock Exchange in 2015. This study found that structural capital is the most common category of intellectual capital disclosed in the annual reports. In addition, most intellectual capital disclosures are discursive, with positive and past-oriented information. However, there is no systematic framework for disclosing intellectual capital information in annual reports. Disclosures made do not have a special pattern and are still random. This finding may contribute to an understanding of how companies communicate intellectual capital information for their own benefit, as well as the benefit of stakeholders, customers and employees.
\end{abstract}

Keywords: Annual Report, Content Analysis, Disclosure, Intellectual Capital

Received: 17 May 2020

Accepted: 31 July 2021

https://doi.org/10.33736/ijbs.4302.2021

\section{INTRODUCTION}

In recent years, dissatisfaction has increased concerning traditional financial reporting and its capacity to provide adequate information to stakeholders about a company's ability to create wealth (Bozzolan et al., 2003). Although financial position statements show the book value and historical value of fixed assets and current assets, they are often unable to disclose the value of the company's intangible assets and intellectual capital (Guthrie et al., 2006). This is particularly found in the knowledge-based economy, marked by rapid technological advances and increasing emphasis on intellectual capital (Stewart, 2001). The high dependence on financial information, and the absence

\footnotetext{
- Corresponding author: Faculty of Economics and Business, Warmadewa University, Jl. Terompong No. 24, Denpasar 80235, Bali, Indonesia; Tel.: +6282147651004; E-mail: partiwi_astuti@yahoo.co.uk.
} 
of intellectual capital information, in traditional accounting systems has become a major obstacle to acknowledging intellectual capital's practical importance (Leadbeater, 1999).

There is no universally-accepted definition of intellectual capital in the literature (Astuti et al., 2021). Intellectual capital has been defined in different ways. Based on the intellectual capital taxonomy developed by previous researchers (i.e., Sveiby, 1997; Bontis, 1998; Jelčić, 2007; Bruggen et al., 2009), intellectual capital is seen as a form of knowledge, intellect and brainpower activity that uses knowledge to create value, which generally consists of human capital, customer capital and structural capital. Human capital shows employee knowledge, competence and brainpower. Customer capital is an established relationship with customers, suppliers, distributors and other groups, in the form of strength, loyalty and satisfaction. Structural capital is an organizational system, practice and process.

Although current financial accounting standards cannot measure the value of intellectual capital, the relationship between intellectual capital and corporate value has encouraged accounting scholars to understand intellectual capital information, which is considered important to the capital market. Intellectual capital information relates to data about current intellectual capital flows and a business's efforts to maintain its intellectual capital for value creation (Fincham \& Roslender, 2003). Research on the usefulness or importance of intellectual capital information in corporate valuation has been conducted via various methods, such as capital market research using associations and event studies; interviews, surveys and experiments with capital market actors; verbal protocol analysis; and analytical report content analysis. Although each research method provides a unique perspective for understanding the type of information used by, or useful to, participants in the capital market, content analysis is one of the most popular methods researchers adopt (Abhayawansa, 2011).

Most researchers are interested in analysing the substance and content of a company's intellectual capital disclosures listed in its annual report, and the first content analysis study on intellectual capital disclosure was one of these - examining intellectual capital data taken from annual reports (Guthrie et al., 1999). Several subsequent studies have also adopted such research methods to find and organise diverse empirical data, including research conducted in Australia (Guthrie \& Petty, 2000), Canada (Bontis, 2003), Hong Kong (Petty, 2003), Ireland (Brennan, 2001), Italy (Bozzolan et al., 2003), Sri Lanka (Abeysekera \& Guthrie, 2004; Abeysekera \& Guthrie, 2005), South Africa (April et al., 2003), and Sweden (Olsson, 2001).

To better understand practices of disclosing and presenting intellectual capital information in annual reports, this study uses content analysis to examine disclosure of intellectual capital from cable companies listed on the Indonesia Stock Exchange. Generally, cable companies belong to the category of miscellaneous industries, cable subsector, and intellectual capital research conducted in these areas is difficult to find. However, as the Global Industry Classification Standard (GICS) claims, cable companies can be categorised with industries having high intellectual capital intensity (Whiting \& Woodcock, 2011). Whiting and Woodcock (2011) suggest that these industries are high-tech - that is technology-based or knowledge intensive. Companies considered to have high intellectual capital intensity utilise intellectual assets well to improve company performance and create competitive advantage. Because cable companies are believed to handle their intellectual assets well, this research, contributing to an understanding of how companies communicate their intellectual capital information in annual reports, seeks to answer 
the question: "What is the pattern of intellectual capital disclosure in the annual reports of cable companies listed on the Indonesia Stock Exchange?"

This study was conducted in three cable companies: Jembo Cable Company Tbk (JECC), KMI Wire and Cable Tbk (KBLI), and Kabelindo Murni Tbk (KBLM). All three comply well with submitting annual reports, which is evident by their timely submissions of their 2015 annual reports. Based on the closing date of December 30, 2015, JECC had 151,200,000 total listed shares; KBLI had 4,007,235,107; and KBLM had 1,120,000,000. The total listed shares of KBLI and KBLM are larger than other cable companies, which were not sampled in this research - Sumi Indo Cable Tbk (IKBI), 306,000,000; Supreme Cable Manufacturing Corporation (SCCO), 205,583,400; and Voksel Electric Tbk (VOKS), 831,120,519. Although JECC's total listed shares are smaller than other cable companies, JECC has a closing price $(\mathrm{Rp} 1,350.00)$ which is higher than other cable companies-KBLI (Rp 119.00), KBLM (Rp 132.00), IKBI (Rp 1,040.00), SCCO (Rp 3,725.00), VOKS (Rp 980.00).

Intellectual capital disclosure can be divided into four points of view: topic dimensions, evidence dimensions, news-tenor dimensions, and orientation dimensions (Abhayawansa, 2011). Topic dimensions include human capital, customer capital and structural capital along with their subcategories. Evidence dimensions include discursive, numerical, monetary and visuals. Newstenor dimensions are divided into positive, neutral and negative. Time orientation dimensions include forward-looking, past-oriented and non-time specific.

Our study found that structural capital is the category of intellectual capital most disclosed in the annual reports of cable companies listed in the Indonesia Stock Exchange. Structural capital also has the widest subcategory in the cable companies' annual reports. Our findings show that most of the studied intellectual capital disclosures are presented discursively, using the past-oriented time dimension, which is dominated by positive disclosure. Additionally, we found that a positive-tenor dominates all types of intellectual capital disclosures, but numerical (non-monetary and monetary) intellectual capital disclosures are dominated by the past-oriented time dimension. Our findings also show that, in any time dimension category, the positive expression still dominates the sampled cable companies' intellectual capital disclosures.

\section{LITERATURE REVIEW}

\subsection{Stakeholder Theory}

The need for intellectual capital disclosure, in particular to provide information required by all stakeholders, cannot be separated from the discussion of stakeholder theory - especially its ethical (moral) or normative branch, which states that stakeholders have the right to be treated fairly by the organization and that the stakeholders' relative power does not negate or grant that right. In an ethical or normative branch, stakeholders are deemed to have intrinsic rights, and those rights should not be violated. Each stakeholder group considers benefits not only for itself because it is able to advance the interests of other groups, such as shareholders (Donaldson \& Preston, 1995).

The concept of stakeholders' inviolate rights in an ethical (moral) or normative branch perspective can be extended to the need for intellectual capital disclosure because all stakeholders have the 
right to obtain information explaining the value of the organization's intangible resource investments. Stakeholders shall be entitled to such information, regardless of whether they will use the information and whether or not the stakeholders have a direct, or indirect, impact on the organization's survival. This theory can be tested in various ways, including content analysis of the company's financial statements (Guthrie et al., 2006). According to Guthrie et al. (2006), financial statements are the most efficient way for organizations to communicate with stakeholder groups that are interested in controlling certain strategic aspects of the organization.

\subsection{Legitimacy Theory}

Legitimacy theory states that organizations continue to work to ensure that companies operate within the boundaries and norms of their respective communities. From this theory's perspective, the company will voluntarily report activity if it is considered important by the society in the company's operating environment. Legitimacy theory is based on the idea that there is a 'social contract' between the company and its society. According to this theory, organizations must continually appear to operate in a manner consistent with societal values (Guthrie \& Parker, 1989). This is often achieved through corporate reporting media.

If an organization feels that legitimacy is questionable, then it can adopt a number of strategies (Lindblom, 1994): (1) educate and inform stakeholders about actual changes in the organization's performance and activities, (2) change the stakeholders' perceptions without changing the actual behaviour, (3) manipulate stakeholder perceptions by diverting attention from issues of concern to other related issues and attracting them with impressive marks, or (4) change and influence external expectations of organizational performance. Companies can use public disclosure to apply each of these strategies. Some empirical research on Social and Environmental Reporting (SER) has also adopted this perspective to explain companies' voluntary disclosure of intellectual capital.

Organizations may use disclosure to show management's concern over social values, or to divert people's attention from negative impacts of organizational activity (Lindblom, 1994). Legitimacy theory is closely linked to intellectual capital reporting and the use of content analysis methods as a measure of such reporting (Guthrie et al., 2006). Companies are more likely to report their intellectual capital if they have a special need to do so. This can happen when a company cannot legitimise its existence based on tangible assets traditionally recognised as symbols of corporate success (Guthrie et al., 2006). Guthrie et al. (2006) argue that content analysis is currently the most appropriate method for measuring the extent of intellectual capital reporting. Thus, legitimacy theory, intellectual capital reporting, and content analysis are interrelated.

\subsection{Intellectual Capital Reporting}

Previous studies concerning intellectual capital have been dominated by measuring it (Stewart, 1997; Sveiby, 1998; Roos et al., 1997). Researchers and practitioners have sought to discover new measurement methods and models of intellectual capital reporting, such as Technology Brokers, the Skandia Navigator, the Intangible Assets Monitor (IAM), or the Intellectual Capital Index. However, such models are often considered too specific to individual companies (Bontis, 2001). It is not easy to find studies on how intellectual capital reporting is structured, and there are no specific guidelines or rules regarding intellectual capital measurement and reporting. 
Some researchers (e.g., Bontis et al., 2000; Sveiby, 1998; Bukh et al., 2001; Roos et al., 1997) suggest financial reporting in two forms: the old financial statements in monetary measures, plus a special report on intellectual capital with non-monetary measures. Bontis et al. (1999) state:

Adding a flow perspective to the stock perspective is akin to adding a profit and loss statement to a balance sheet in accounting. The two perspectives combined (or the two reporting tools, in the case of accounting) provide much more information than any single one alone. At the same time, intellectual capital flow reporting presents some additional challenges in terms of complexity.

To date, international accounting bodies, such as the International Federation of Accountants (IFAC), the International Accounting Standards Committee (IASC), and the Society of Management Accountants of Canada (SMAC) are also examining the intellectual capital management and reporting framework.

The limitations of conventional financial accounting standards and the existence of intellectual capital practices have resulted in a discussion on obligations for standardising and disclosing intellectual capital. However, it is very difficult to standardise the 'soft intangible' (Lambert, 1998). In addition, voluntary standards will be precise and flexible, rather than mandatory, due to current, rapid changes in intellectual capital (Grojer \& Johanson, 1999). Brennan and Connell (2000) argue that accounting conservatism for the intangible indicates there is little chance for regulators to develop intellectual capital standards. Thus, voluntary disclosure of intellectual capital is an appropriate approach for companies to meet the stakeholders' information needs.

Despite the difficulties, there are several reasons for companies to disclose intellectual capital information - one of the most important being reducing information asymmetry between firms and external information users. According to Andriessen (2004), information asymmetry can lead to misallocation of capital, which ultimately leads to social costs, such as unemployment and reduced productivity. In addition, traditional accounting's incapability to present intellectual capital information disadvantages investors who lack internal knowledge (Leadbeater, 1999; Vergauwen \& van Alem, 2005). Intellectual capital disclosure can help increase the relevance of the financial report's value. Failure to provide relevant information about intellectual capital may lead to a deterioration of the company's financial position and the loss of its long-term competitiveness (Cañibano et al., 1999). In fact, when using financial statements that do not report intellectual capital, investors have difficulty providing an assessment of the company's value for resource allocation. Similarly, managers find it difficult to determine the relevant intangible investment required for a company's operations. Such realizations highlight the importance of providing relevant information for managers and users of other financial statements.

Companies are also motivated to disclose intellectual capital information to earn employees' and stakeholders' trust (Backhuijs et al., 1999; Meer-Kooistra \& Ziljstra, 2001; Bornemann \& Leitner, 2002). By publishing information relating to intellectual capital, companies can prevent losses stemming from rumours and hearsay (Bornemann \& Leitner, 2002). Intellectual capital information can also be used as a marketing tool (Meer-Kooistra \& Ziljstra, 2001). Edvinsson (1997) points out that, in most established companies, such as Intel, Microsoft and Netscape, there is a big difference between market value and book value, and that difference is called 'hidden value'. Disclosure of intellectual capital information enables firms to provide the public with the 
company's true value, including its hidden value, and value creation capabilities. This will ultimately enhance the company's reputation (Bruggen et al., 2009).

In accounting literature, recent research has focused on the informative role of external reporting for the effectiveness of capital market functions (Healy \& Palepu, 2001). Indeed, previous studies showed that companies disclosing intellectual capital, when compared to firms with low disclosure rates, had reduced capital costs (Botosan, 1997); decreased borrowing costs (Sengupta, 1998); increased stock performance, which was not related to current and expected earnings (Healy et al., 1999); and produced higher-priced stock correlations with future earnings (Gelb \& Zarowin, 2002). This affirms the relevance of increased, external narrative reporting, as well as the impairment of information provided in financial statements (Breton \& Taffler, 2001).

\subsection{Review of Using Content Analysis in Intellectual Capital Literature}

Content analysis of annual reports has been used by a number of intellectual capital researchers because it is a good instrument for measuring comparative positions and trends in reporting (Guthrie et al., 2004). Annual reports have been used to investigate corporate intellectual capital reporting practices (Bozzolan et al., 2003; Brennan, 2001; Guthrie et al., 1999; Guthrie et al., 2003; Olsson, 2001) and to investigate differences in reporting among companies in various countries (Subbarao \& Zeghal, 1997). Researchers in Australia were early adopters of content analysis as a method for testing organizational practices in managing and reporting intellectual capital. Guthrie and Petty (2000) conducted content analysis on the annual reports of 20 major Australian companies listed on the Australian Securities Exchange to understand the extent to which companies report their intellectual capital.

Guthrie and Petty (2000) use a framework developed by Sveiby (1997), which categories intangibles according to their relationship to the organization's internal structure, external structure or internal competence. The results found that the key components of intellectual capital are poorly understood, not adequately identified, not efficiently managed and not consistently reported. Guthrie and Petty (2000) also show that the disclosure percentage for each element of intellectual capital is $30 \%$ for human capital, $30 \%$ for organizational capital (internal structure) and $40 \%$ for customer capital (external structure). Furthermore, Guthrie and Petty (2000) found that: 1) most intellectual capital disclosures (95\%) are presented separately and none are presented quantitatively, which indicates that intellectual capital is difficult to quantify; 2) companies disclose external capital most often; 3) the reporting and disclosure of intellectual capital is still partial and not comprehensive; and 4) as a whole, companies emphasise that intellectual capital is essential to success in the face of future competition. However, this cannot yet be translated into a solid and coherent message for annual reports.

Brennan (2001) conducted a similar study at a company in Ireland, analysing the annual reports of ten private companies and 11 companies listed on the Irish Stock Exchange. Brennan (2001) uses the same framework as Guthrie and Petty (2000) in conducting the content analysis report. The findings are similar to those in Australia. Irish companies have a substantial level of non-physical, intangible, intellectual capital assets. Such assets are rarely referred to in annual reports and, when referred to, it is in the most qualitative terms. Brennan (2001) found that the level of intellectual capital disclosure of Irish companies was still low. Research conducted by Olsson (2001) tested the annual reports of 18 major companies in Sweden and developed a list of five elements to ensure 
the level of human capital reporting. The study found that no firm uses more than seven percent of the reporting space to deliver human resource information in its annual report. In addition, the reported information was found to be very unfavourable in terms of quality or level of disclosure.

\section{METHODOLOGY}

This study's research sample is made up of the cable companies listed on the Indonesia Stock Exchange in 2015. There were six cable companies-IKBI, JECC, KBLI, KBLM, SCCO, and VOKS - but three of them-IKBI, SCCO, and VOKS — did not submit an annual report in 2015. Therefore, the sample includes only three companies: JECC, KBLI, and KBLM. This study's data sources take the form of secondary data (i.e., from annual reports accessed through the Indonesia Stock Exchange website, namely www.idx.co.id.). This study uses techniques of documentation as its data collection method.

This research does not intend to merely measure the extent to which various intellectual capital categories are cited in annual reports. Rather, it was conducted to determine and understand intellectual capital disclosure patterns in annual reports by examining what and how intellectual capital information is communicated in such reports. Therefore, the methodology developed by Abhayawansa (2011) is suitable for use in this study. Abhayawansa (2011) developed a methodology that enables generation of valid and reliable inferences about what and how intellectual capital information is communicated, based on a four-dimensional framework for coding intellectual capital references into topics and three communication attributes-evidence, news tenor, and time orientation.

Based on the content analysis method, this study adopts the main aspects of the categorization scheme, as studied by Abhayawansa (2011), which consists of the dimensions of topic, evidence, time orientation and news-tenor. These dimensions allow researchers to examine how different types of intellectual capital information are communicated. The topic dimensions, text units and information items relating to intellectual capital are classified into three categories-human capital, structural capital and customer capital - in accordance with the taxonomy developed by previous researchers (e.g., Sveiby, 1997; Bontis, 1998; Jelčić, 2007; Bruggen et al., 2009). These three main categories are combined with Abhayawansa's (2011) 34 intellectual capital subcategories. Abhayawansa (2011) formulated the categories and subcategories after an extensive review of accounting and management literature and testing it at the coding stage. Based on the annual report of the cable companies sampled in this study, various pieces of information presented in the reports show suitability, if the information is classified into the intellectual capital categories and subcategories developed by Abhayawansa (2011).

The dimensions of evidence, text units and information items relating to intellectual capital are classified into four mutually exclusive categories, as described in Table 1. 
Table 1: Operational Definitions of Evidence Categories

\section{Category}

Discursive (non-numerical)

Numerical (non-monetary)

Monetary (numerical)

Visual

\section{Operational Definition}

The intellectual capital subcategory is expressed only in written or narrative forms, or as cells in a table, which convey non-numerical meanings by corresponding to column and row headers.

The information disclosed uses actual figures with non-financial characteristics to communicate or emphasise the intellectual capital subcategory.

The information disclosed uses actual numbers with financial characteristics to communicate or emphasise the intellectual capital subcategory.

The intellectual capital subcategory is communicated through graphs, charts or diagrams.

Sources: Abhayawansa (2011).

The time orientation dimensions, text units and information items related to intellectual capital are classified into three categories, as shown in Table 2.

Table 2: Operational Definition of Time Orientation Categories

\begin{tabular}{cl}
\hline \hline Category & \multicolumn{1}{c}{ Operational Definition } \\
\hline \multirow{3}{*}{ Forward looking } & $\begin{array}{l}\text { Communication of a company's potential future value creation through } \\
\text { intellectual capital. This category contains current text units and information } \\
\text { relating to investments in existing or future intellectual capital, intellectual } \\
\text { capital against future (or expected) benefits/losses and future intellectual capital } \\
\text { expressed alongside current or past intellectual capital. } \\
\\
\text { Communication of a company's value realization today, or in the previous } \\
\text { period, which has resulted from intellectual capital. This category contains text } \\
\text { units and information relating to benefits presently obtained or accepted by a } \\
\text { company due to current or past intellectual capital. It may also include } \\
\text { references to intellectual capital in a backward-looking manner. }\end{array}$ \\
& $\begin{array}{l}\text { A disclosure of intellectual capital that is neither backward- nor forward- } \\
\text { looking. The main characteristic of the content categorised here is that } \\
\text { intellectual capital is not related to value or other outcome. }\end{array}$ \\
\hline \hline
\end{tabular}

Sources: Abhayawansa (2011).

In the news-tenor dimension, text units and information items related to intellectual capital are classified into three categories as shown in Table 3. 
Table 3: Operational Definitions of News-Tenor Categories

\begin{tabular}{cc}
\hline \hline Category & Operational Definition \\
Positive & $\begin{array}{c}\text { Information about the potential benefits of the company's intellectual capital, } \\
\text { its beneficial use and its disclosure as an indication of an enterprise's strength. } \\
\text { Information about the lack of corporate intellectual capital. It indicates that the } \\
\text { company does not reach the expected or reasonable level or that it is in an } \\
\text { unfavourable position compared to other companies' ownership or utilization } \\
\text { of intellectual capital. }\end{array}$ \\
Neutral & $\begin{array}{c}\text { Information about the company's non-positive and non-negative intellectual } \\
\text { capital. }\end{array}$ \\
\hline \hline
\end{tabular}

Sources: Abhayawansa (2011).

\section{RESULTS AND DISCUSSION}

\subsection{Topic Based Analysis}

The topic-based analysis makes it possible to understand what intellectual capital information is communicated in annual reports. Content analysis of the sample annual reports reveal 697 text units and information items related to intellectual capital. Table 4 shows the frequency distribution between the categories and subcategories of intellectual capital.

Table 4: Distribution Frequency between Categories and Subcategories of Intellectual Capital

\begin{tabular}{|c|c|c|c|c|c|c|c|c|}
\hline \multirow{3}{*}{ Panel A } & \multicolumn{6}{|c|}{ Distribution Frequency } & \multirow{2}{*}{\multicolumn{2}{|c|}{ Total }} \\
\hline & \multicolumn{2}{|c|}{ JECC } & \multicolumn{2}{|c|}{ KBLI } & \multicolumn{2}{|c|}{ KBLM } & & \\
\hline & $\begin{array}{c}\text { Frequenc } \\
\mathbf{y}\end{array}$ & $\%$ & $\begin{array}{c}\text { Frequenc } \\
\mathbf{y}\end{array}$ & $\%$ & $\begin{array}{c}\text { Frequenc } \\
\mathbf{y}\end{array}$ & $\%$ & Frequency & $\%$ \\
\hline $\begin{array}{c}\text { Human } \\
\text { capital }\end{array}$ & 47 & 23.74 & 84 & 35.90 & 84 & 31.70 & 215 & 30.85 \\
\hline $\begin{array}{l}\text { Structural } \\
\text { capital }\end{array}$ & 136 & 68.69 & 122 & 52.14 & 156 & 58.87 & 414 & 59.40 \\
\hline $\begin{array}{c}\text { Customer } \\
\text { capital }\end{array}$ & 15 & 7.58 & 28 & 11.97 & 25 & 9.43 & 68 & 9.76 \\
\hline $\begin{array}{c}\text { Total } \\
\text { intellectual } \\
\text { capital }\end{array}$ & 198 & $\begin{array}{c}100.0 \\
0\end{array}$ & 234 & $\begin{array}{c}100.0 \\
0\end{array}$ & 265 & $\begin{array}{c}100.0 \\
0\end{array}$ & 697 & $\begin{array}{c}100.0 \\
0\end{array}$ \\
\hline \multicolumn{7}{|c|}{ Panel B } & Frequency & $\%$ \\
\hline \multicolumn{9}{|c|}{ Human Capital } \\
\hline \multicolumn{7}{|c|}{ Educational qualifications } & 40 & 5.74 \\
\hline \multicolumn{7}{|c|}{ Employee attitude, commitment \& satisfaction } & 0 & 0.00 \\
\hline \multicolumn{7}{|c|}{ Employee entrepreneurship } & 0 & 0.00 \\
\hline \multicolumn{9}{|c|}{ Employee } \\
\hline \multicolumn{7}{|c|}{ a. Commissioners and directors } & 0 & 0.00 \\
\hline \multicolumn{7}{|c|}{ b. Other executive } & 0 & 0.00 \\
\hline \multicolumn{7}{|c|}{ c. Other employees } & 1 & 0.14 \\
\hline \multicolumn{7}{|c|}{ Equality } & 3 & 0.43 \\
\hline
\end{tabular}


Management team
Remuneration and incentive schemes

a. Commissioners and directors

0.29

b. Other executive

b. Other employees

2

$\begin{array}{cc}10 & 1.43 \\ 0 & 0.00\end{array}$

$1 \quad 0.14$

Skills and capabilities

$\begin{array}{lcr}\text { a. Commissioners and directors } & 0 & 0.00 \\ \text { b. Other executive } & 0 & 0.00 \\ \text { c. Other employees } & 5 & 0.72 \\ \text { raining and development } & 15 & 2.15\end{array}$

Work experience

a. Commissioners and directors $\quad 14.20$

b. Other executive $\quad 11 \quad 1.58$

c. Other employees $\quad \begin{array}{ll}1 & 0.14\end{array}$

$\begin{array}{lll}\text { Working environment } & 27 & 3.87\end{array}$

Structural Capital

$\begin{array}{lll}\text { Business model } & 0 & 0.00\end{array}$

$\begin{array}{lll}\text { Corporate culture } & 20 & 2.87\end{array}$

$\begin{array}{lrr}\text { Corporate governance } & 137 & 19.66\end{array}$

$\begin{array}{lll}\text { Intellectual property } & 0 & 0.00\end{array}$

$\begin{array}{lll}\text { Information systems \& information technology } & 0 & 0.00\end{array}$

$\begin{array}{lll}\text { Management philosophy } & 22 & 3.16\end{array}$

Management processes, policies \& practices $\quad 131 \quad 18.79$

Organisational \& business expertise $\quad 13 \quad 1.87$

Organisational \& management structure $\quad 17 \quad 2.44$

$\begin{array}{lll}\text { Quality } & 54 & 7.75\end{array}$

Research \& development $\quad 0 \quad 0.00$

$\begin{array}{lcr}\text { Strategy } & 20 & 2.87\end{array}$

$\begin{array}{lrr}\text { Technology (other) } & 0 & 0.00\end{array}$

Customer capital

Brands

$1 \quad 0.14$

Business collaborations
a. Joint ventures
b. Mergers \&acquisitions
c. Private-public partnerships
d. Strategic alliances
e. Subsidiaries \& associate companies
$\begin{array}{ll}0 & 0.00 \\ 0 & 0.00\end{array}$
$\begin{array}{ll}0 & 0.00\end{array}$
$1 \quad 0.14$
Corporate image \& reputation
$22 \quad 3.16$
Customers, relationship, satisfaction \& loyalty $\quad 5 \quad 0.72$
Customers (other)
3.16
Distribution

$2 \quad 0.29$
External contacts, licensing \& franchise agreements
$\begin{array}{ll}4 & 0.57 \\ 2 & 0.29\end{array}$
Financial relations
Government and other relationships
$\begin{array}{ll}0 & 0.00 \\ 0 & 0.00\end{array}$
Market share
1.29

Table 4 shows that structural capital is the most common category of intellectual capital disclosed in the annual reports, followed by human capital and customer capital. Due to the nature of the 
sampled reports, these structural capital disclosures mostly discuss the companies' operations during the observation period.

Panel B in Table 4 provides detailed information on the frequency of communicating subcategories of intellectual capital. The subcategories under structural capital are the most communicated, when compared to the subcategories of human capital and customer capital. Of the structural capital subcategories, corporate governance, as well as management processes, policies and practices, are the most disclosed. These are followed by information about the experience of commissioners and directors, which are subcategories of human capital. However, several subcategories of structural capital, human capital and customer capital appear to be ignored in the companies' annual reports.

The sampled companies also stated that human resources are very important to them. However, the small disclosure of human capital information shown in Table 4 (30.85\% of all intellectual capital disclosures) indicates that this statement is not supported by recognition of human resource value. The same findings are also shown by Guthrie et al. (2006), who conducted research on companies in Australia and Hong Kong and found that many companies claim human resources are most important, but this is not significantly supported by disclosures recognising the importance of human intellectual capital to the enterprise. The findings indicate a gap between acknowledging the importance of intellectual capital and taking steps to show how important intellectual capital is. The low disclosure of human capital in the annual reports can indicate that the companies are concerned the information might be misused by competitors, as suggested by Williams (2001), who argues that a larger proportion of human capital information will attract unwanted attention. Negative impacts, such as possible piracy against the companies' best human capital, could be the reason for not disclosing optimal information about human capital in annual reports.

Content analysis of the annual reports also found no systematic framework for providing intellectual capital information. This is in line with Guthrie and Petty (2000) and Guthrie et al. (2006), who found that a systematic framework for intellectual capital disclosure has not yet been applied in the reports of the companies examined. In fact, there is no patterns of intellectual capital disclosure in the sampled annual reports at all (Guthrie \& Petty, 2000). Such disclosures arise randomly (Guthrie \& Petty, 2000; Guthrie et al., 2006). This study also uncovered similar findings. The sample Indonesian cable companies discussed intellectual capital but had no special disclosure patterns.

The second level of the intellectual capital subcategory included in this study's classification scheme allows further analysis of the disclosure frequency of business collaboration information. It also allows a determination of whether human capital information largely regards commissioners and directors, other executives or other employees. Content analysis conducted on the companies' annual reports shows that the most common types of business collaborations mentioned are subsidiaries and associate companies (95.65\%, see Table 5). This type of limited business collaboration can hinder a company's potential for achieving competitive advantage. Therefore, management efforts are needed to expand business collaboration-for example, by conducting joint ventures, strategic alliances, private-public partnerships, and mergers and acquisitions. This will strengthen the company's intellectual capital and contribute to achieving competitive advantage. 
Table 5: Frequency of Reference for Business Collaboration Types

\begin{tabular}{ccc}
\hline \hline Types of Business Collaborations & \multicolumn{2}{c}{ Frequency of } \\
& References \\
\cline { 2 - 3 } & n & $\%$ \\
\hline Joint ventures & 0 & 0.00 \\
Mergers and acquisitions & 0 & 0.00 \\
Private-public partnerships & 0 & 0.00 \\
Strategic alliances & 1 & 4.35 \\
Subsidiaries \& associate companies & 22 & 95.65 \\
\hline Total business collaborations & 23 & 100.00 \\
\hline \hline
\end{tabular}

Meanwhile, the disclosure of human capital is closely related to company management, which includes commissioners and directors, other executives and other employees (Table 6).

Table 6: Frequency of Reference for Employee Type

\begin{tabular}{|c|c|c|c|c|c|c|c|}
\hline \multirow[t]{2}{*}{ Human Capital Subcategories } & \multicolumn{2}{|c|}{$\begin{array}{l}\text { Commissioners } \\
\text { and Directors }\end{array}$} & \multicolumn{2}{|c|}{$\begin{array}{c}\text { Other } \\
\text { Executives }\end{array}$} & \multicolumn{2}{|c|}{$\begin{array}{c}\text { Other } \\
\text { Employees }\end{array}$} & \multirow{2}{*}{$\begin{array}{c}\text { Total } \\
\text { Sampl } \\
\text { (n) }\end{array}$} \\
\hline & $\mathbf{n}$ & $\%$ & $\mathbf{n}$ & $\%$ & $\mathbf{n}$ & $\%$ & \\
\hline Employees (other) & 0 & & 0 & & 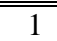 & & 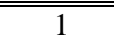 \\
\hline Remuneration \& incentive schemes & 10 & & 0 & & 1 & & 11 \\
\hline Skills \& capabilities & 0 & & 0 & & 5 & & 5 \\
\hline Work experience & 99 & & 11 & & 1 & & 111 \\
\hline Total & 109 & 85.16 & 11 & 8.59 & 8 & 6.25 & 128 \\
\hline
\end{tabular}

Table 6 shows that information about commissioners and directors is the most frequently disclosed at $85.16 \%$. The companies' annual reports show very little information about other executives and other employees.

\subsection{Evidence Based Analysis}

The analysis in this and subsequent sections relates to how intellectual capital information is communicated in the annual reports. Table 7 presents a two-way analysis of evidence and main intellectual capital categories.

Table 7: Two-Way Analysis between Evidence and Main Category Intellectual Capital

\begin{tabular}{|c|c|c|c|c|c|c|c|c|c|}
\hline & \multicolumn{2}{|c|}{ Discursive } & \multicolumn{2}{|c|}{$\begin{array}{c}\text { Non- } \\
\text { Monetary }\end{array}$} & \multicolumn{2}{|c|}{ Monetary } & \multicolumn{2}{|c|}{ Visual } & \multirow[t]{2}{*}{ Total } \\
\hline & $\mathbf{n}$ & $\%$ & n & $\%$ & $\mathbf{n}$ & $\%$ & n & $\%$ & \\
\hline "Human capital & 203 & 94.86 & 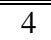 & 1.87 & 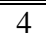 & 1.87 & 3 & 1.40 & 214 \\
\hline Structural capital & 304 & 73.25 & 52 & 12.53 & 43 & 10.36 & 16 & 3.86 & 415 \\
\hline Customer capital & 47 & 69.12 & 12 & 17.65 & 7 & 10.29 & 2 & 2.94 & 68 \\
\hline Total intellectual capital & 554 & 79.48 & 68 & 9.76 & 54 & 7.75 & 21 & 3.01 & 697 \\
\hline
\end{tabular}


Table 7 shows that most intellectual capital disclosures are substantially discursive (79.48\%), while numerical (non-monetary and monetary) disclosures account for $17.51 \%$. The number of visual intellectual capital disclosures is the least at $3.01 \%$.

The large number of discursive intellectual capital disclosures indicates that much of the information contained in the annual reports-disclosed in narrative or written forms or in table cells - conveys non-numerical meaning in relation to intellectual capital subcategories. The small disclosure in visual forms is caused by the fact that most sampled companies prefer discursive disclosure and do not include graphs, charts or diagrams as supporting media to communicate intellectual capital information in their annual reports. This may be because information with a non-numerical meaning presented in narrative or written form, or disclosed in a table cell, can be more readily understood than the same information presented visually.

Looking at the cross-tabulation between the categories of evidence and the main categories of intellectual capital, human capital information appears to be more frequently disclosed discursively (94.86\%). Meanwhile, non-monetary disclosure mostly reveals customer capital information $(17.65 \%)$. Structural capital information appears to be more frequently disclosed monetary $(10.36 \%)$ and visual $(3.86 \%)$.

\subsection{News-Tenor Based Analysis}

Table 8 shows the two-way analysis between news-tenors and the main categories of intellectual capital.

Table 8: Two-Way Analysis between News-Tenors and Main Categories Intellectual Capital

\begin{tabular}{cccccccc}
\hline \hline & \multicolumn{2}{c}{ Negative } & \multicolumn{2}{c}{ Neutral } & \multicolumn{2}{c}{ Positive } & \multirow{2}{*}{ Total } \\
\cline { 2 - 6 } & $\mathbf{n}$ & $\mathbf{\%}$ & $\mathbf{n}$ & $\mathbf{\%}$ & $\mathbf{n}$ & $\boldsymbol{\%}$ & \\
\hline Human capital & 3 & 1.40 & 47 & 21.96 & 164 & 76.64 & 214 \\
Structural capital & 34 & 8.19 & 84 & 20.24 & 297 & 71.57 & 415 \\
Customer capital & 8 & 11.76 & 10 & 14.71 & 50 & 73.53 & 68 \\
\hline Total intellectual capital & 45 & 6.46 & 141 & 20.23 & 511 & 73.31 & 697 \\
\hline \hline
\end{tabular}

Table 8 clearly shows that the sampled companies' intellectual capital disclosure is mostly positive $(73.31 \%)$, whereas the negative disclosure is only $6.46 \%$, and the remaining $(20.23 \%)$ is neutral disclosure. The presence of positive intellectual capital disclosure indicates that the sampled companies seek to convey information about their intellectual capital's benefits or potential benefits, that they believe their intellectual capital to be profitable and that intellectual capital is the companies' potential power. In addition, the sampled companies also seek to show that they are maintaining their image, which is indicated by the small, negative disclosures in the annual reports.

Table 8 also illustrates that the positive disclosure of human capital information (76.64\%) is greater than that for structural capital and customer capital. It is also interesting to note Table 8's high negative disclosure rate $(11.76 \%)$ and the low level of neutral disclosure $(14.71 \%)$ for customer capital information when compared with human and structural capital. 


\subsection{Time Orientation Based Analysis}

Table 9 shows the two-way analysis between time orientation and intellectual capital's main categories.

Table 9: Two-Way Analysis between Time Orientation and Main Category Intellectual Capital

\begin{tabular}{|c|c|c|c|c|c|c|c|}
\hline & \multicolumn{2}{|c|}{ Forward-Looking } & \multicolumn{2}{|c|}{ Non-Time Specific } & \multicolumn{2}{|c|}{ Past-Oriented } & \multirow{2}{*}{ Total } \\
\hline & $\mathbf{n}$ & $\%$ & $\mathbf{n}$ & $\%$ & $\mathbf{n}$ & $\%$ & \\
\hline Human capital & 7 & 3.26 & 74 & 34.42 & 134 & 62.33 & 215 \\
\hline Structural capital & 55 & 13.29 & 116 & 28.02 & 243 & 58.70 & 414 \\
\hline Customer capital & 6 & 8.82 & 16 & 23.53 & 46 & 67.65 & 68 \\
\hline Total intellectual capital & 68 & 9.76 & 206 & 29.56 & 423 & 60.69 & 697 \\
\hline
\end{tabular}

Table 9 indicates that the past-oriented time dimension dominates the annual reports (60.69\%), followed by the non-time specific category and the forward-looking category. The past-oriented dimension dominates because the companies spent much space describing their performance during the observation period. This is understandable, since annual reports are prepared to explain a company's performance over a period. Therefore, based on observations of the companies' annual reports during the observation period, the intellectual capital is largely past or historical events that reflect the company's performance.

Significant variations in the time orientation of disclosures are evident among the three main intellectual capital categories. Observing the sampled companies, we uncovered interesting findings concerning the low level of forward-looking disclosures (3.26\%) and the high level of non-time specific disclosures $(34.42 \%)$ in human capital. Structural capital has the highest number of forward-looking disclosures (13.29\%).

\subsection{Two-Way Analysis between Evidence, News-Tenor and Time Orientation}

Table 10 presents two-way analysis results between news-tenor and evidence categories.

Table 10: Two-Way Analysis between Category News-Tenor and Evidence

\begin{tabular}{cccccccc}
\hline \hline & \multicolumn{2}{c}{ Positive } & \multicolumn{2}{c}{ Negative } & \multicolumn{2}{c}{ Neutral } & \multirow{2}{*}{ Total } \\
\cline { 2 - 7 } & $\mathbf{n}$ & $\mathbf{\%}$ & $\mathbf{n}$ & $\mathbf{\%}$ & $\mathbf{n}$ & $\mathbf{\%}$ & \\
\hline Discursive & 421 & 74.38 & 21 & 3.71 & 124 & 21.91 & 566 \\
Non-monetary & 45 & 72.58 & 12 & 19.35 & 5 & 8.06 & 62 \\
Monetary & 35 & 67.31 & 11 & 21.15 & 6 & 11.54 & 52 \\
Visual & 12 & 70.59 & 0 & 0.00 & 5 & 29.41 & 17 \\
\hline Total & 513 & 73.60 & 44 & 6.31 & 140 & 20.09 & 697 \\
\hline \hline
\end{tabular}

Table 10 shows the positive-tenor dominance in all types of intellectual capital disclosures based on the evidence dimensions. The discursive disclosures are predominantly presented positively $(74.38 \%$ ) compared to numerical (non-monetary, $72.58 \%$; monetary, 67.31\%) and visual (70.59\%) disclosures. When intellectual capital information is presented numerically (non-monetary and monetary), negative-tenors are used more often than with discursive disclosures. 
The interaction between time orientation and evidence of intellectual capital information is shown in Table 11.

Table 11: Two-Way Analysis between Time Orientation and Evidence

\begin{tabular}{cccccccc}
\hline \hline & \multicolumn{2}{c}{$\begin{array}{c}\text { Forward- } \\
\text { Looking }\end{array}$} & \multicolumn{2}{c}{$\begin{array}{c}\text { Non-Time } \\
\text { Specific }\end{array}$} & \multicolumn{2}{c}{$\begin{array}{c}\text { Past- } \\
\text { Oriented }\end{array}$} & \multirow{2}{*}{ Total } \\
\cline { 2 - 7 } & $\mathbf{n}$ & $\mathbf{\%}$ & $\mathbf{n}$ & $\mathbf{\%}$ & $\mathbf{n}$ & \% & \\
\hline Discursive & 65 & 11.44 & 202 & 35.56 & 301 & 52.99 & 568 \\
Non-monetary & 0 & 0.00 & 1 & 1.64 & 60 & 98.36 & 61 \\
Monetary & 1 & 2.04 & 1 & 2.04 & 47 & 95.92 & 49 \\
Visual & 0 & 0.00 & 6 & 31.58 & 13 & 68.42 & 19 \\
\hline Total & 66 & 9.47 & 210 & 30.13 & 421 & 60.40 & 697 \\
\hline \hline
\end{tabular}

Table 11 shows that numerical (non-monetary and monetary) disclosures of intellectual capital are predominantly past-oriented, respectively at $98.36 \%$ and $95.92 \%$. This indicates that the sampled companies have the same plan for communicating non-monetary and monetary intellectual capital information.

Table 12 shows the cross-tabulation of news-tenor categories with time orientation.

Table 12: Two-Way Analysis between News-Tenor and Time Orientation

\begin{tabular}{cccccccc}
\hline \hline & \multicolumn{3}{c}{ Positive } & \multicolumn{2}{c}{ Negative } & \multicolumn{3}{c}{ Neutral } & \multirow{2}{*}{ Total } \\
\cline { 2 - 7 } & $\mathbf{n}$ & $\mathbf{\%}$ & $\mathbf{n}$ & $\mathbf{\%}$ & $\mathbf{n}$ & $\boldsymbol{\%}$ & \\
\hline Forward-looking & 66 & 97.06 & 2 & 2.94 & 0 & 0.00 & 68 \\
Past-oriented & 297 & 70.21 & 43 & 10.17 & 83 & 19.62 & 423 \\
Non-time specific & 148 & 71.84 & 4 & 1.94 & 54 & 26.21 & 206 \\
\hline Total & 511 & 73.31 & 49 & 7.03 & 137 & 19.66 & 697 \\
\hline \hline
\end{tabular}

Table 12's most important finding is that intellectual capital disclosures are dominated by positive expression, regardless of time orientation. Negative disclosures are the least common among all time orientation categories. Most positive expressions are forward-looking (97.06\%), while nontime specific disclosure has a high proportion of neutral expression (26.21\%).

\section{CONCLUSION}

In the annual reports of cable companies listed on the Indonesia Stock Exchange in 2015, there are 697 text units and information items relating to intellectual capital disclosure. Structural capital is the category of intellectual capital that is disclosed most in the annual reports, and structural capital's subcategories are also the most disclosed. The most common types of disclosed business collaborations are subsidiaries and associated companies, and, considering employees, information on commissioners and directors is expressed more frequently than that for any other executives or employees. 
Disclosure of suboptimal intellectual capital-i.e., when most disclosures are dominated by structural capital and there are several subcategories of human capital, customer capital, and structural capital not seen in the annual report - has various implications for management. For example, efforts must be made to create or revise policies, which allows management to further explore intellectual capital emergence. Policies related to human capital must also be made or revised, so information can be presented in annual reports. Such human capital areas would include employee entrepreneurship; employee attitudes, commitments, and satisfaction; and commissioners, directors, and other executives (including their skills, capabilities, and remuneration schemes).

Management also must make various efforts to increase customer capital, so information, such as business collaborations (joint venture, mergers and acquisitions, private-public partnerships), financial relations, and government and other relationships, can be disclosed in annual reports. Although structural capital is the most disclosed category of intellectual capital, a number of subcategories, which also require management attention, are still overlooked, such as business models, research and development, intellectual property, information systems and information technology, and other technologies. Optimal disclosure of intellectual capital information is expected to provide more comprehensive information about the organization, the success and failure of knowledge development, and the strengths and weaknesses of individual knowledge areas.

Concerning the evidence dimension, the majority of intellectual capital disclosures are substantially discursive - conveying non-numerical meanings and taking narrative or written forms or being disclosed in a table's cell. The news-tenors are mostly positive, showing that the companies want to convey the benefits, or potential benefits, of their intellectual capital, how that intellectual capital has been used constructively and that their intellectual capital is one of their strengths. Concerning time orientation, the cable companies generally preferred the past-oriented category, because the purpose of preparing annual reports is to explain a company's performance in a given period.

Positive news-tenor dominates in all types of disclosures, and, from all intellectual capital disclosures in the evidence domain, numerical (non-monetary and monetary) disclosures are predominantly past-oriented. No matter the time orientation, intellectual capital disclosures are expressed in the positive tenor.

The lack of a systematic framework for intellectual capital disclosure and the randomness of disclosures, which have no specific patterns as evidenced in the Indonesian cable companies' 2015 annual reports, implies that the capital market supervisory body must create regulations for intellectual capital disclosure standards. The companies' statements that human resources are very important, unaccompanied by the recognition of such resource value in the annual reports, suggests that the cable companies sampled - and perhaps, by extension, other companies - must be more open to providing human capital disclosures in annual reports, regardless of piracy threats or the misuse of such information by competitors.

The results of this study provide a challenge for accounting standards compilers to consider whether intellectual capital is presented as additional information in the annual report. If needed, accounting standards compilers are required to set guidelines regarding intellectual capital—e.g., 
guidelines for preparing intellectual capital statements. In addition, the government can also set regulations mandating company obligations to disclose intellectual capital.

This study is limited because it only takes samples from one type of company-cable companies. It has also researched a small number of samples during only one annual reporting period. In Indonesia, a similar study was conducted by Anggraini (2013), who also examined one type of company-banking companies - with one annual reporting period and mapped patterns of intellectual capital disclosure. Consequently, further research can be done in other company types, as long as they are companies with high intellectual capital intensity. In future studies, academics and researchers can also expand this theoretical foundation by stretching the sample into different industries and extending the observation period.

This research only focuses on content analysis of annual reports regarding intellectual capital disclosure. The study does not explore the viewpoint of the company's management team regarding disclosure practices. Therefore, further research can conduct interviews with management teams, who may have different information, so as to complement and support the present content analysis.

\section{ACKNOWLEDGEMENT}

The authors would like to thank the anonymous referees for constructive comments on earlier version of this paper.

\section{REFERENCES}

Abeysekera, I., \& Guthrie, J. (2004). Human capital reporting in a developing nation. British Accounting Review, 36(3), 251-268.

Abeysekera, I., \& Guthrie, J. (2005). An empirical investigation of annual reporting trends of intellectual capital in Sri Lanka. Critical Perspectives on Accounting, 16, 151-163.

Abhayawansa, S. (2011). A methodology for investigating intellectual capital information in analyst reports. Journal of Intellectual Capital, 12(3), 446-476.

Andriessen, D. (2004). IC valuation and measurement: classifying the state of the art. Journal of Intellectual Capital, 5(2), 230-242.

Anggraini, Y. D. (2013). Pemetaan pola pengungkapan intellectual capital perusahaan-perusahaan perbankan yang terdaftar pada Bursa Efek Indonesia Periode 2011. Calyptra: Jurnal Ilmiah Mahasiswa Universitas Surabaya, 2(2), 1-20.

April, K. A., Bosma, P., \& Deglon, D. A. (2003). IC measurement and reporting: establishing a practice in SA mining. Journal of Intellectual Capital, 4(2), 165-180.

Astuti, P. D., Chariri, A., \& Rohman, A. (2021). Tri hita karana's philosophy and intellectual capital: evidence from the hotel industry in Indonesia. Montenegrin Journal of Economics, 17(3), 169-180.

Backhuijs, J., Holterman, W., Oudman, R., Overgoor, R., \& Zijlstra, S. (1999, June 9-10). Reporting on intangible assets. Measuring and Reporting Intellectual Capital: Experience, Issues, and Prospects. International Symposium, Technical Meeting, Amsterdam. https://www.oecd.org/industry/ind/1947807.pdf

Bontis, N. (1998). Intellectual capital: an exploratory study that develops measures and models. 
Management Decision, 36(2), 63-76.

Bontis, N. (2001). Assessing knowledge assets: a review of the models used to measure intellectual capital. International Journal of Management Reviews, 3(1), 41-60.

Bontis, N. (2003). Intellectual capital disclosure in Canadian corporations. Journal of Human Resource Costing \& Accounting, 7(1), 9-20.

Bontis, N., Dragonetti, N. C., Jacobsen, K., \& Roos, G. (1999). The knowledge toolbox: a review of the tools available to measure and manage intangible resources. European Management Journal, 17(4), 391-402.

Bontis, N., Keow, W. C. C., \& Richardson, S. (2000). Intellectual capital and business performance in Malaysian industries. Journal of Intellectual Capital, 1(1), 85-100.

Bornemann, M., \& Leitner, K. H. (2002). Measuring and reporting intellectual capital: the case of a research technology organisation. Singapore Management Review, 24, 7-19.

Botosan, C. A. (1997). Disclosure level and the cost of equity capital. The Accounting Review, 72(3), 323-349.

Bozzolan, S., Favotto, F., \& Ricceri, F. (2003). Italian annual intellectual capital disclosure. An empirical analysis. Journal of Intellectual Capital, 4(4), 543-558.

Brennan, N. (2001). Reporting intellectual capital in annual reports: evidence from Ireland. Accounting, Auditing \& Accountability Journal, 14(4), 423-436.

Brennan, N., \& Connell, B. (2000). Intellectual capital: current issues and policy implications. Journal of Intellectual Capital, 1(3), 206-240.

Breton, G., \& Taffler, R. J. (2001). Accounting information and analyst stock recommendation decisions: a content analysis approach. Accounting and Business Research, 31(2), 91-101.

Bruggen, A., Vergauwen, P., \& Dao, M. (2009). Determinants of intellectual capital disclosure: evidence from Australia. Management Decision, 47(2), 233-245.

Bukh, P., Larsen, H., \& Mouritsen, J. (2001). Constructing intellectual capital statements. Scandinavian Journal of Management, 17, 87-108.

Cañibano, L., Covarsí, M. G. A., \& Sánchez, M. P. (1999). The value relevance and managerial implications of intangibles: a literature review. https://www.oecd.org/sti/ind/1947974.pdf

Donaldson, T., \& Preston, L. E. (1995). The stakeholder theory of the corporation: concepts, evidence, and implications. Academy of Management, 20(1), 65-91.

Edvinsson, L. (1997). Developing intellectual capital at Skandia. Long Range Planning, 30(3), 366-373.

Fincham, R., \& Roslender, R. (2003). Intellectual capital accounting as management fashion: a review and critique. European Accounting Review, 12(4), 781-795.

Gelb, D. S., \& Zarowin, P. (2002). Corporate disclosure policy and the informativeness of stock prices. Review of Accounting Studies, 7, 33-52.

Grojer, J., \& Johanson, U. (1999, June). Voluntary guidelines on the disclosure of intangibles: a bridge over troubled water? [Paper presentation]. International Symposium Measuring and Reporting Intellectual Capital: Experiences, Issues and Prospects, Amsterdam.

Guthrie, J., Johanson, U., Bukh, P., \& Sanchez, P. (2003). Intangibles and the transparent enterprise: new strands of knowledge. Journal of Intellectual Capital, 4(4), 429-440.

Guthrie, J., \& Parker, L. D. (1989). Corporate social reporting: a rebuttal of legitimacy theory. Accounting and Business Research, 19(76), 343-352.

Guthrie, J., \& Petty, R. (2000). Intellectual capital: Australian annual reporting practices. Journal of Intellectual Capital, 1(3), 241-251.

Guthrie, J., Petty, R., Ferrier, F., \& Wells, R. (1999). There is no accounting for intellectual capital in Australia: a review of annual reporting practices and the internal measurement of 
intangibles. OECD Symposium on Measuring and Reporting of Intellectual Capital, 1-134. Guthrie, J., Petty, R., \& Ricceri, F. (2006). The voluntary reporting of intellectual capital. Comparing evidence from Hong Kong and. Journal of Intellectual Capital, 7(2), 254-271.

Guthrie, J., Petty, R., \& Yongvanich, K. (2004). Using content analysis as a research method to inquire into intellectual capital reporting. Journal of Intellectual Capital, 5(2), 282-293.

Healy, P. M., Hutton, A. P., \& Palepu, K. G. (1999). Stock performance and intermediation changes surrounding sustained increases in disclosure. Contemporary Accounting Research, 16(3), 485-520.

Healy, P. M., \& Palepu, K. G. (2001). Information asymmetry, corporate disclosure, and the capital markets: a review of the empirical disclosure literature. Journal of Accounting and Economics, 31, 405-440.

Jelčić, K. (2007). Intellectual capital: handbook of IC management in companies. http:www2.hgk.hr/hrdc/IC_Management-Handbook.pdf.

Meer-Kooistra, J. van der M., \& Ziljstra, S. M. (2001). Reporting on intellectual capital. Accounting, Auditing \& Accountability Journal, 14(4), 456-476.

Lambert, R. A. (1998). Customer satisfaction and future financial performance discussion of are nonfinancial measures leading indicators of financial performance? An analysis of customer satisfaction. Journal of Accounting Research, 36, 37-46.

Leadbeater, C. (1999). New measures for the new economy. International Symposium Measuring and Reporting Intellectual Capital: Experience, Issues, and Prospects, 1-42.

Lindblom, C. (1994). The implications of organizational legitimacy for corporate social performance and disclosure [Paper presentation]. Critical Perspectives on Accounting Conference, New York.

Olsson, B. (2001). Annual reporting practices: information about human resources in corporate annual reports in major Swedish companies. Journal of Human Resource Costing \& Accounting, 6(1), 39-52.

Petty, R. (2003). The disclosure of intangible information by listed companies in Hong Kong.

Roos, J., Roos, G., Dragonetti, N. C., \& Edvinsson, L. (1997). Intellectual capital: navigating in the new business landscape. Macmillan Press.

Sengupta, P. (1998). Corporate disclosure quality and the cost of debt. The Accounting Review, 73(4), 459-474.

Stewart, T. A. (1997). Intellectual capital: the new wealth of organizations. Doubleday.

Stewart, T. A. (2001). The wealth of knowledge: intellectual capital and the twenty first century organization. Doubleday.

Subbarao, A., \& Zeghal, D. (1997). Human resources information disclosure in annual reports: an international comparison. Journal of Human Resource Costing and Accounting, 2(2), 53-73.

Sveiby, K. E. (1997). The new organizational wealth. Managing \& measuring knowledge-based assets. Berrett-Koehler.

Sveiby, K. E. (1998). Measuring intangibles and intellectual capital-an emerging first standard. https://www.sveiby.com/files/pdf/measuring-intangibles-and-intellectual-capital.pdf

Vergauwen, P. G., \& van Alem, F. J. (2005). Annual report IC disclosures in The Netherlands, France and Germany. Journal of Intellectual Capital, 6(1), 89-104.

Whiting, R. H., \& Woodcock, J. (2011). Firm characteristics and intellectual capital disclosure by Australian companies. Journal of Human Resource Costing \& Accounting, 15(2), 102-126.

Williams, S. M. (2001). Is intellectual capital performance and disclosure practices related? Journal of Intellectual Capital, 2(3), 192-203. 